\section{Pictorial delights in marine science}

THIS year has seen the publication of five books on various aspects of life in the seas and oceans. All are published to a high standard and are sometimes called 'coffee-table books', designed to attract the casual looker rather than the hard reader. All of them are intelligible to the non-scientist but some would be useful in sixth-form (advanced school) libraries or for general reading by undergraduates, thus giving a wide potential market.

Probably the most information is packed into The Undersea (Cassell: London; Macmillan: New York; £12.50; $\$ 27.50$ ), a book of grand dimensions edited by N. C. Fleming of the UK Institute of Oceanographic Sciences. It contains chapters by different authors on the ocean floor, the water itself, plant life, salt-water animals, the ocean resources, the use of ocean space, underwater archaeology, diving and divers, submarine craft, and marine law and politics. This is oceanology rather than oceanography. The book is expensive but the standard of production is high, with hundreds of black-and-white and coloured photographs and diagrams. A major criticism is that the legends for these are often inadequate and some of the diagrams are poorly conceived. Although some of the chapters are difficult, for example that on the ocean floor, most of them will be understood by the lay reader. There is a good index and modest bibliography.

The other four recent books are more limited in scope. In The Seashore and Its Wildlife (Orbis: London; £5.95), Robert Burton, a naturalist author, sets out to describe the nature of the shore, how it is formed, its variability in different parts of the world, and its flora and fauna. This delightful book is packed with excellent colour photographs, and the text is readable and informative, with a good index and bibliography. It must rate as a best buy in terms of production standard and price, if one wants a book on the shore, but I would rate it educationally only up to sixth-form level as general reading.

In a rather similar category is Animals of the Oceans: The Ecology of Marine Life by Martin Angel and Tegwyn Harris (Eurobook/Peter Lowe: London; £4.75), which contains many excellent photographs but also some poor and distinctly garish diagrams. There are chapters on the ocean environment, the ocean's fishes, the edge of the sea, coral reefs and mangrove swamps, plankton, the open sea, air-breathers, and man and the ocean. There is a short bibliography and glossary, and an index. This book is obviously good value for money; it is elementary in style but readable and fairly informative. Perhaps the authors tried to do too much in the space available.

Finally, there are two books on marine mammals. In The Encyclopaedia of Sea Mammals (Hart-Davis, MacGibbon: London; £12) D. J. Coffey sets out to produce something approaching an encyclopaedia. There are three main sections: dolphins, whales and porpoises; seals, sea lions and walruses; and dugongs, sea cows and manatees. With each group there is an alphabetically arranged list of features on life history, ecology, exploitation, and so on, followed by a list of species, each briefly described. There are some indifferent diagrams, some really identification. Both books bring out well the lore surrounding sea mammals, especially the Cetaceans, and they rightly point to the problems of conservation. I find their strictures on the use of dolphins in warfare less easy to understand. It seems to me that using dolphins to flush out enemy frogmen or carry limpet mines is little different from the widely accepted use of police dogs or horses.

When reviewing popular or semipopular books of such a high standard of production, an inevitable comparison is made with the strictly technical literature, where $£ 20-30$ is a common price range.

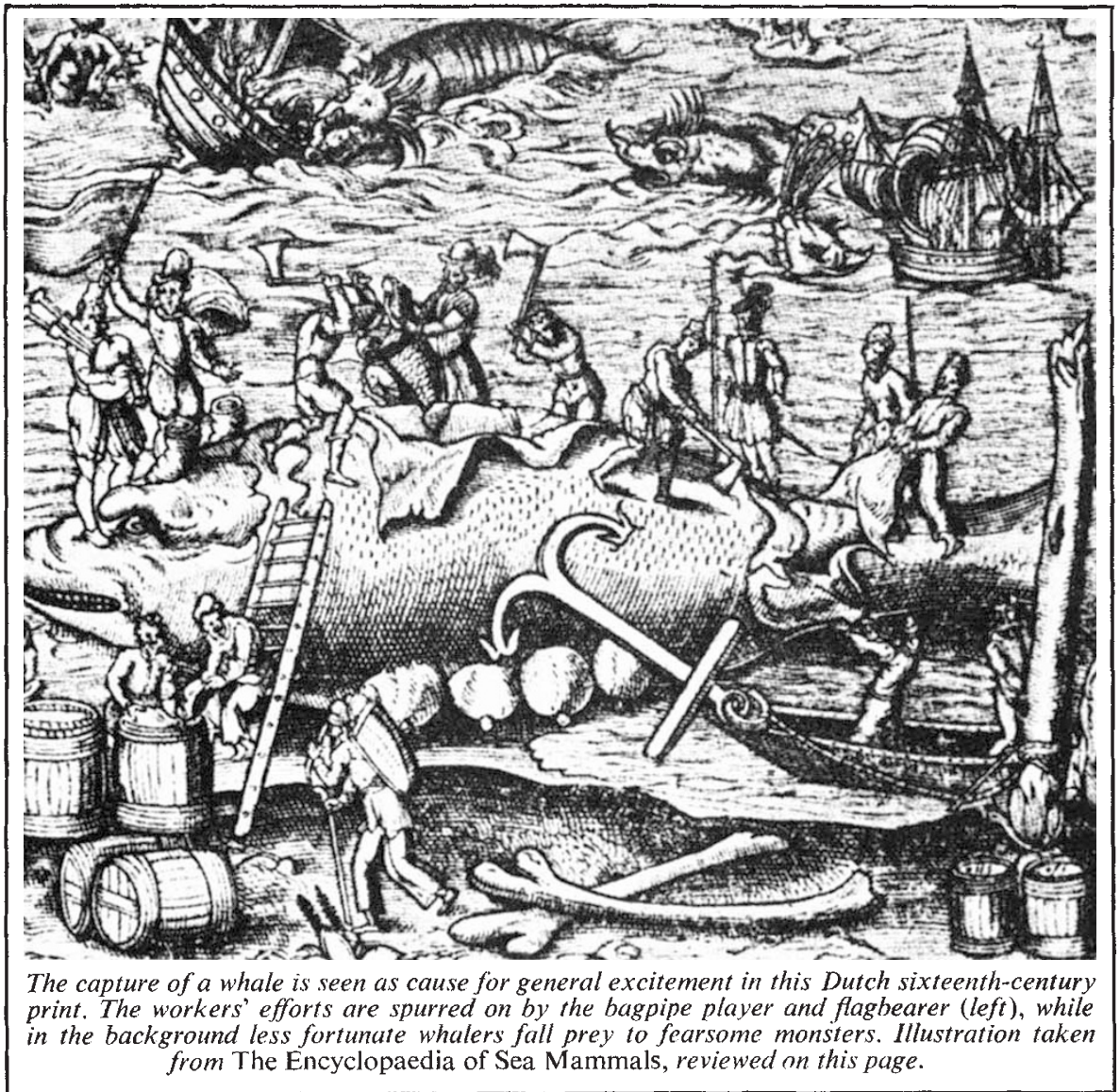

excellent photographs, and copies of prints and other pictures dealing with the subject. The academic standard is about six-form level. Although the book could be used to identify some of the species described, it is by no means a key to identification, and many of the photographs are taken for dramatic effect rather than recognition. At $£ 12$, this book is by far the highest-priced for its size. Perhaps the price is set high because the book is of more limited interest and the potential sales therefore lower.

Mammals of the Seas by R. M. Martin (Batsford: London; f4.95) is a book of similar length, style and standard to the Coffey book. The difference in price, however, is astonishing. Species are listed and there is a glossary, index and bibliography. It is a pity that neither book contains a really good key or section on
Presumably, such technical books sell $1000-5000$ copies. What is the estimated sale for the books under review? The publishers no doubt have done their market research and are exploiting the present vogue in natural history and the oceans. Sales will go up before Christmas, since such books will catch the eye of parents seeking presents; these books may get into school and public libraries, and individuals may indulge themselves. As a marine biologist, I like The Undersea best. All the books, however, contain an excellent range of colour photographs, and even if the text of some of these books is banal in places they are a pictorial delight.

J. H. S. Blaxter

J.H. S. Blaxter is Senior Principal Scientific Officer at the Dunstaffnage Marine Research Laboratory, Oban, Argyll, UK. 